\title{
Gondnoksági perekben tapasztalt visszásságok, a jogalkalmazás egységességének hiánya
}

\section{BOROS ILONA - SZEGI PÉTER GYÖRGY}

Magyarország 2007-ben ratifikálta az ENSZ Fogyatékossággal Élő Személyek Jogairól szóló Egyezményét (a továbbiakban: CRPD). 2014-tôl pedig az ebböl következő nemzetközi elvárásoknak és szakmai elveknek megfelelöen módosult a Polgári Törvénykönyv (a továbbiakban: Ptk.) is, bevezetve többek között a támogatott döntéshozatal intézményét. A tanulmány célja áttekinteni a hazai gondnoksági perek jogalkalmazói gyakorlatának azóta eltelt, utóbbi öt évét. Tekintettel arra, hogy a majd hatvanezer gondnokság alatt élö ember számára sorsdöntő jelentöségü a cselekvőképességüket érintő bírósági döntés, így a szerzők az alapjogkorlátozás alkotmányos keretei között elemzik a gondnoksági perek gyakorlatát. Ebből az aspektusból vizsgáljuk a szükségesség és arányosság, a fokozatosság elveinek megvalósulását, a gondnokság alá helyezés törvényi feltételeinek különböző értelmezését, a „szakértői perekben" rejlö veszélyek, vagy éppen az ügycsoportok egyenkénti vizsgálatának kérdéseit.

Kulcsszavak: CRPD, fogyatékossággal élő személyek, gondnokság, cselekvőképesség, támogatott döntéshozatal, fokozatosság, alapjogi teszt, választójog, igazságügyi szakértő

\section{Inconsistencies in Guardianship Cases}

Hungary ratified the UN Convention on the Rights of Persons with Disabilities (hereinafter: CRPD) in 2007. The Hungarian Civil Code was accordingly amended in 2014. Although the new Civil Code introduced supported decision making, it did not fully abolish guardianship. The aim of this study is to evaluate the implementation of the new rules through recent jurisprudence of Hungarian courts. Due to the fact that guardianship judgements have a major impact on the basic human rights of nearly 60,000 persons with disabilities who are placed under some form of guardianship, the authors chose to analyse civil law cases in the constitutional framework. A detailed analysis is provided on the application of legal principles set forth in the new Civil Code, such as necessity, proportionality, graduality in the chosen guardianship cases. This study aims at pointing out how far the implementation of international standards has gone in relation to the constitutional restriction of fundamental rights, examining the dangers 


\begin{abstract}
prevalent in cases influenced by expert opinions and contributing to the effective support of persons with disabilities to respect, protect and fulfil their fundamental rights on an equal basis with others.
\end{abstract}

Keywords: legal capacity, guardianship CRPD, necessity and proportionality test, supported decision making, will or interest of the individual, case-law analysis, role of expert opinions, right to vote

\title{
Bevezetés
}

A mentális zavarral élő állampolgárok cselekvőképességét a bíróságok gyakorta korlátozzák, mert úgy ítélik meg, hogy nem rendelkeznek az ügyeik viteléhez szükséges belátási képességgel. Az ilyen intézkedéseknek az a kimondott céljuk, hogy megvédjék a mentális zavarral élő embereket attól, hogy rossz döntéseket hozzanak, és kiszolgáltatottá váljanak a rosszhiszeműen kötött szerződéseknek.

A tapasztalatok szerint ${ }^{1}$ azonban a cselekvőképesség korlátozása ellentétes a rehabilitációs folyamat irányával, és a gondnokság alá helyezett személy gyógyulására, felépülésére kifejezetten káros hatással van, mivel megerősíti és tartósítja függő helyzetét. Meggyőző bizonyítékok támasztják alá azt, hogy a felépülés egyik legfontosabb feltétele a magánéleti döntések feletti rendelkezési jog megőrzése, illetve visszaszerzése. ${ }^{2}$ A gondnokság alá helyezés nem nyújtja a remélt életvezetési, szociális gondoskodásbeli támogatást, amire a legtöbb érintettnek valójában szüksége lenne. Akit gondnokság alá helyeznek, az önállóan nem dönthet a magánéletét érintő legalapvetőbb kérdésekben, mint például házasságkötés, gyermekvállalás, tartózkodási hely szabad megválasztása, egészségügyi ellátás igénybevétele. A gondnokság alá helyezett személyek megfoszthatók választójoguktól. Ráadásul ez a mechanizmus gyakorta és rendszerszerüen vezet ahhoz, hogy akaratuk ellenére nagy létszámú szociális intézetben helyeznek el fogyatékossággal élő vagy idős embereket. Mivel a gondnokság alá helyezés súlyos alapjogkorlátozáshoz vezet, így ezek a perek alapjogi szempontból különösen érzékenyek.

Fentiek miatt a Társaság a Szabadságjogokért jogvédő szervezet (a továbbiakban: TASZ) két évtizede monitorozza a gondnoksági perek bírósági gyakorlatát. A szervezet ingyenes jogi tanácsadást, jogsegélyt, és számos esetben jogi képviseletet is nyújt gondnokság alatt álló, illetve olyan személyeknek, akiknek gondnokság alá helyezését kezdeményezték. E jogászi munka során szerzett tapasztalat, hogy a jogalkalmazói gyakorlat a gondnoksági perekben távolról sem egységes. Az alábbi tematikus elemzés a jogvédő szervezet munkája során szerzett tapasztalatok, a jogalkalmazás

1 A gondnokság alá helyezés az egyén jogvédelme érdekében ugyan, de jogkorlátozást jelent; ebben az értelemben hatása ellentétes irányú, mint a rehabilitációé. HuszÁr-KunCz 1998, 274. 
során leggyakrabban felmerülö eltérések összefoglalása, amely tanulmányt az Eötvös Loránd Tudományegyetem Bárczi Gusztáv Gyógypedagógiai Kar (ELTE-BGGyK) oktatói értékes meglátásokkal, kiegészítésekkel láttak el. Az elemzés alapjául egyrészt az új Polgári Törvénykönyv hatálybalépése után indult bírósági eljárások szolgáltak, amelyekben a TASZ ügyvédei peres képviselőként jártak el, másrészt az a több száz megkeresés, amely a TASZ jogsegélyszolgálatához érkezett az elmúlt évek során.

2014. március 15-én hatályba lépett az új Polgári Törvénykönyv és háttérjogszabályai. Az új kódex átalakította a cselekvőképesség és gondnokság alá helyezés rendszerét, és bevezette a támogatott döntéshozatal, valamint az előzetes jognyilatkozat intézményeit. Sajnálatos módon azonban továbbra is megtartotta a cselekvőképességet korlátozó, sőt a teljesen korlátozó gondnokság lehetőségét is. ${ }^{3}$

Öt évvel az új törvény hatálybalépését követően indokoltnak és időszerűnek tűnik a gondnoksági perek joggyakorlatával kapcsolatos tapasztalatok áttekintése, különös tekintettel arra, hogy 2017. december 31 -én, Magyarországon 57983 fón állt cselekvőképességet érintő gondnokság alatt. Az ő számukra sorsdöntő, hogy már az elsőfokú eljárás is jogszerű módon folyjon le, ugyanis döntő többségük nem tud élni a rendelkezésükre álló jogorvoslati lehetőséggel.

Elemzésünkben egységesen érintett félként utalunk a gondnoksági perekben érintett fogyatékossággal élő emberekre függetlenül attól, hogy felperesként (például gondnokság megszüntetése iránti per) vagy alperesként (gondnokság alá helyezési per) szerepelnek az adott eljárásban. A Ptk. a mentális zavarral élő ember fogalmat használja. Tanulmányunkban - a gondnoksági eljárással érintett emberek eltérő fogyatékosságai alapján a mentális zavarral élő ember alatt a pszichoszociális fogyatékossággal élö - korábbi fogalomhasználattal élve: pszichiátriai beteg -, az intellektuális fogyatékossággal élő - korábbi fogalomhasználattal élve: értelmi fogyatékos - és az autizmussal élö embereket egyaránt értjük.

\section{Az alapjogok szükségtelen, illetve aránytalan korlátozása, a fokozatosság elvének sérülése}

A cselekvőképesség megvonása vagy korlátozása minden esetben súlyosan érinti a gondnokolt önrendelkezési jogát, a magánélethez való jogát, ezeken keresztül emberi méltóságát. A Fogyatékossággal élő személyek jogairól szóló ENSZ Egyezményt (a továbbiakban: ENSZ Egyezmény) Magyarország a 2007. évi XCII. törvényben hirdette ki. A törvény előtti egyenlőségről rendelkező 12. cikk Magyarországot is kötelezi, hogy a cselekvőképesség gyakorlására vonatkozó valamennyi intézkedés, a nemzetközi emberi joggal összhangban, megfelelő és hatékony biztosítékokat tartalmazzon a visszaélések megelőzésére. Az ilyen biztosítékok garantálják, hogy a cselekvőképesség gyakorlására vonatkozó intézkedések tiszteletben tartják a személy jogait, akaratát és választásait, összeférhetetlenségtől és indokolatlan befolyástól

3 Az erről szóló kritikánk részletesebben olvasható itt: Joghalál az új Ptk.-ban. 2014.

4 Szociális statisztikai évkönyv - 2017. 2018, 65. 
mentesek, arányosak és a személy körülményeire szabottak, a lehető legrövidebb időre vonatkoznak, továbbá, hogy a hatáskörrel rendelkező, független és pártatlan hatóság vagy igazságügyi szerv rendszeresen felülvizsgálja azokat. A biztosítékok azzal arányosak, amilyen mértékben az adott intézkedések érintik a személy jogait és érdekeit. Megjegyezzük, hogy az ENSZ Egyezmény végrehajtását ellenőrző Fogyatékos Személyek Jogai Bizottsága (a továbbiakban: CRPD Bizottság) értelmezésében az ENSZ Egyezmény elutasítja a helyettes döntéshozatalt, különösképpen a cselekvőképességet kizáró, vagy - a magyar jogi terminológiával élve - teljesen korlátozó gondnokság intézményét, és a támogatott döntéshozatal bevezetésére kötelezi a tagállamokat. Támogatott döntéshozatal alatt olyan jogi megoldásokat ért, amelyek úgy nyújtanak támogatást fogyatékos személyek döntéshozatalában, hogy eközben nem korlátozzák az érintettek cselekvőképességét. A CRPD Bizottság ezen intézkedések hiánya miatt marasztalt el számos országot, köztük Magyarországot is. ${ }^{5}$

Az Emberi Jogok Európai Bírósága a gondnokság alá helyezéssel összefüggésben állapított meg jogsérelmet különösen a magánélethez való jog, a tisztességes tárgyaláshoz való jog, a szabadsághoz és biztonsághoz való jog és a hatékony jogorvoslathoz való jog vonatkozásában a Shtukaturov kontra Oroszország, ${ }^{6}$ az X. és Y. kontra Horvátország, ${ }^{7}$ a Stanev kontra Bulgária ${ }^{8}$ és a Lashin kontra Oroszország ${ }^{9}$ ügyekben. Az Alapvető Jogok Biztosa a magyarországi rendszer átfogó vizsgálata során 2016-ban megállapította, hogy a gondnoksági rendszer komoly problémákkal küzd, ami a kiszolgáltatott gondnokoltak jogsérelméhez vezet. ${ }^{10}$

Az Alkotmánybíróság (a továbbiakban: $\mathrm{AB}$ ) gyakorlatából mindazonáltal egyértelmű, hogy a gondnokság intézménye - kellő garanciákkal körülbástyázva - megengedett a magyar alkotmányos jogrendben. ${ }^{11} \mathrm{Az} \mathrm{AB}$ által felállított, és 2012 óta az Alaptörvényben szövegszerűen is megjelenő szükségesség és arányosság követelménye a polgári anyagi jog szintjén is kifejezést nyert. Az új Polgári Törvénykönyvben a gondnokság alá helyezéssel cselekvőképességükben érintett személyekre vonatkozó szabályok jelentősen módosultak a szükségesség és arányosság elvének megfelelően. Ilyen lényeges újítás, hogy már a cselekvőképesség részleges korlátozására is csak akkor kerülhet sor, - a fokozatosság követelményének megfelelően - ha az érintett személy jogainak védelme más módon - például az új jogintézményként megjelenő támogatott döntéshozatal által - nem biztosítható.

A támogatott döntéshozatal progresszivitását az adja, hogy a gondnokság intézményénél kevésbé korlátozza az érintett alapjogait, továbbá jelentősen több és hatékonyabb támogatást tud biztosítani számára. Az új kódex ezzel a megoldással egyszerre tudta kiküszöbölni a cselekvőképesség korlátozását, és egyúttal támogatást,

Concluding observations of the Committee on the Rights of Persons with Disabilities, Hungary. 2012.

Shtukaturov v. Russia, Judgement of 27 March 2008, no. 44009/05.

X. and Y. v. Croatia, Judgement of 3 November 2011, no. 5193/09.

Stanev v. Bulgaria, Judgement of 17 January 2012, no. 36760/06.

Lashin v. Russia, Judgement of 22 January 2013, no. 33117/02.

10 Az alapvető jogok biztosának Jelentése az AJB 2709/2016. számú ügyben.

11 74/2009. (VII. 10.) AB határozat. 
gondoskodást nyújtani az azt igénylő személy számára. Sajnálatosan azonban alig-alig élnek a bírák ezen előremutató jogintézménnyel, így álláspontunk szerint a gondnoksági perek során többnyire sérül a fokozatosság elve. Ezt igazolja az a 2017-es adat, amely szerint Magyarországon 57983 fó állt cselekvőképességet érintő gondnokság alatt és csupán 167 fö volt támogatott döntéshozatalban. ${ }^{12}$

Ahogy ezek a számok is mutatják, bár az új Ptk. már több mint négy éve hatályos, a fokozatosság elvének érvényesülésével kapcsolatban továbbra is bizonytalan a jogalkalmazás. Tapasztalataink szerint ennek egyik oka, hogy a felperes gyámhatóságok kereseti kérelmükben gyakran a cselekvőképesség teljes korlátozását kérik, azért, hogy később a bizonyítási eljárás során felmerülő tények - a kereseti kérelemhez kötöttség elve okán - ne korlátozzák a bírót az egyes ügycsoportok meghatározásában. Ez a gyakorlat helytelen és ellentétes a szükségesség és arányosság, illetve a fokozatosság elvével. A cselekvési autonómia drasztikus korlátozása esetében éppen fordítva kellene a gyámhivataloknak eljárnia: megvizsgálni, hogy elsődlegesen a támogatott döntéshozatal elegendő védelmet nyújt-e, amennyiben nem, úgy az ügycsoportoknak mi az a lehető legszűkebb köre, amely szükséges az érintett jogainak védelméhez.

A fokozatosság elvének alkalmazásával kapcsolatos további bizonytalanság abból fakad, hogy a bíróságok nem egységesek abban a kérdésben, hogy a cselekvőképesség korlátozása során alkalmazzák-e a szükségesség és arányosság tesztjét, vagy sem. A bíróságok számos esetben osztották jogi érvünket, amely szerint a fokozatosság elvéből következik, hogy a szükségesség és arányosság követelményét alkalmazva csak akkor kerülhet sor a cselekvőképesség, mint alkotmányos alapjog korlátozására, ha az feltétlenül szükséges és az érintett személy jogainak védelme a cselekvőképességet nem érintő más módon - például támogatott döntéshozatallal - nem biztosítható. ${ }^{13}$

Számtalan olyan ítélettel is találkoztunk azonban, amelyek csupán utalnak a fokozatosság követelményére, vagy idézik a Ptk. 2:19. \$ (4) bekezdését, de a különleges mérlegelési szempontokat már nem alkalmazzák, a szabályból semmilyen következtetést nem vonnak le. ${ }^{14}$

Több olyan ítélettel is találkoztunk, amelyek egyáltalán nem említik - még a vonatkozó Ptk. szöveg idézésével sem - a fokozatosság követelményét, megfeledkezve annak alapelvi jelentőségéről. ${ }^{15}$

A szükségesség és arányosság követelményének alkalmazása, valamint a per során felmerült bizonyítékok gondos mérlegelése két egymástól eltérő döntéshozatali

12 Központi Statisztikai Hivatal egyedi kérésre összeállított táblázatos adatállománya. Az adatszolgáltatás időpontja: 2018. május 11.

13 Ilyen bírói érvelést olvashatunk a Gyulai Járásbíróság 5.P.20.277/2017/21. sz. ítéletében, a Debreceni Járásbíróság 56.P.23.875/2016/39. sz. ítéletében, a Budapest Környéki Törvényszék 14.Pf.21.639/2016/7. sz. ítéletében.

14 Például: Székesfehérvári Járásbíróság 3.P.22.706/2016/20. sz. ítélete, Székesfehérvári Járásbíróság 8.P.21.437/2017/19. sz. ítélete, Budaörsi Járásbíróság 2.P.20.635/2015/35. sz. ítélete.

15 Különösen: Szigetvári Járásbíróság 12.P.20.101/2016/17. sz. ítélete, Pesti Központi Kerületi Bíróság 19.P.102.422/2015/13. sz. ítélete, Székesfehérvári Járásbíróság, 13.P.20.422/2015/14. sz. ítélete. 
módszertan, amelyek eltérő nézőpontból rendkívül eltérő döntéseket eredményeznek, ezzel megkérdőjelezve az ítélkezési gyakorlat egységességét.

Szükséges lenne tehát annak egyértelmű kimondása, hogy a bíró a cselekvőképesség korlátozása során, mivel alapjog korlátozására kerül sor, szükségességi és arányossági vizsgálatot végez.

\section{Egyes ügycsoportok meghatározása, az ítéletek indokolásának hiányossága}

Amennyiben úgy határoz a bíróság, hogy az érintett fél jogainak védelméhez szükséges a gondnokság alá helyezés, a fokozatosság elvét követve, következő lépésként el kell döntenie, hogy elegendő-e a cselekvőképességet csak részlegesen korlátozni, vagy teljesen korlátozó gondnokság elrendelésére van szükség. A részlegesen korlátozó gondnokság esetén meg kell határoznia a korlátozással érintett ügycsoportokat. Az ügycsoportok kiválasztásának módja azonban nem egységes szempontok alapján történik. A bíróság az ügycsoportok meghatározásánál természetesen kötve van a gyámhatóság kereseti kérelméhez. Ahogy azonban arra az előző pontban utaltunk, tapasztalataink szerint a gyámhatóságok felülsúlyozzák azon ügycsoportokat, amelyekben jogkorlátozást látnak szükségesnek, gyakran a legsúlyosabb korlátozást - vagyis teljesen korlátozó gondnokság alá helyezést - kérve a bíróságtól. Tipikus esetnek mondható a Székesfehérvári Járásbíróság előtt indult 8.P.21.437/2017 sz. ügy, amelyben a cselekvőképességet teljesen korlátozó gondnokság elrendelését indítványozta a felperes gyámhatóság, majd alperesi érveink hatására módosította kérelmét végül egyetlen ügycsoportra.

A bizonyítás a gondnokság alá helyezés iránt indított perben a felperest terheli. A bizonyítási eljárás során keletkezett bizonyítékok és az összes körülmény gondos mérlegelése után dönt a bíró, hogy mely ügycsoportok tekintetében tartja indokoltnak a korlátozást. A Ptk. indokolása (V. cím, 2. pont) szerint „[a] cselekvőképesség korlátozásának szükségességét minden egyes ügycsoport esetén indokolni kell. Az elsőfokú bíróságnak minden egyes ügycsoportban meg kell indokolnia, hogy milyen jogi és ténybeli indokok alapozzák meg a cselekvőképesség korlátozását. Az ítélet megfelelő indokolása nem pusztán formai kötelezettség, hanem ezen múlik az ítélet meggyőző ereje. Az indokolási kötelezettség hiányossága lényeges eljárási szabálysértés, amely az ítélet hatályon kívül helyezéséhez vezethet".

Ennek ellenére számtalan ügyben bebizonyosodott, hogy amennyiben az érintett személy nem képes jognyilatkozatot tenni egy adott ügycsoport vonatkozásában, pusztán erre a tényre alapítva rendelt el korlátozást más ügycsoportokban is a bíróság. Az ilyen ítéletek indokolásai csupán általánosságban a belátási képesség csökkenésének mértékét rögzítik, azt röviden indokolják, azonban nem térnek ki külön-külön az egyes ügycsoportokra. ${ }^{16}$ A Nagykátai Járásbíróság 8.P.20.389/2016 sz. ügyben

16 Ilyen határozat született a Miskolci Törvényszék 1.Pf.21.337/2015/4. sz. ítéletében, a PKKB.

9.P.103.486/2013/56. sz. ítéletében, a Veszprémi Járásbíróság 8.P.21.001/2014/20-I. sz. és 41-I. sz. kiegészítő ítéletében, és a Székesfehérvári Járásbíróság 13.P.20.422/2015/14. sz. ítéletében. 
hozott ítéletét az alperes fellebbezése folytán - többek között - éppen azon az alapon helyezte hatályon kívül a Budapest Környéki Törvényszék 1.Pf.21.698/2017/6. számú végzésével, mert az elsőfokú bíróság nem tett eleget azon indokolási kötelezettségnek, hogy a korlátozni rendelt ügycsoportokat egyenként vizsgálja.

Más bíróságok - helyesen - a belátási képesség csökkenésének hatását külön-külön értékelik az egyes ügycsoportok vonatkozásában. ${ }^{17}$

Szükséges, hogy minden ítélet indokolásában megjelenjen az egyes ügycsoportok tekintetében elvégzett szükségességi és arányossági vizsgálat levezetése. Ennek elmaradása súlyosan sérti a gondnokság alá helyezett személy alapvető jogait, az ítéletek indokolásának nagyfokú eltérése pedig sérti a jogbiztonság elvét.

\section{A cselekvőképesség-korlátozás feltételeinek nem egységes értelmezése}

A cselekvőképességet korlátozó gondnokság elrendeléséhez három ok együttes fennállása szükséges (Ptk. 2:19. \$ és 2:21. \$). Egyrészt az érintett károsodott mentális egészségügyi állapotának a ténye és súlyossága (szakértői kérdés). Másrészt az, hogy ez az állapot az érintett belátási képességére olyan kihatással legyen, amely a személyes döntési autonómiájának a korlátozását indokolja, azaz hogy a szakértői vélemény és egyéb körülmények figyelembevételével a bíró szükségesnek ítélje a cselekvőképesség korlátozását (jogkérdés). Harmadrészt, hogy egyéni körülményeire, illetve családi és társadalmi kapcsolataira - jellemzően azok hiányára - tekintettel szükség legyen a jogkorlátozásra (ténykérdés).

\section{Mentális zavar}

A feltétel a jogi norma szintjén „mentális zavara következtében” kitételként jelenik meg a Ptk.-ban. Ez orvosszakértői kérdés. A TASZ jogsegélyszolgálatának tapasztalatai szerint a szakvélemények rendkívül eltérőek tartalmi szempontból, ami nem elsősorban az érintett felek pszichoszociális vagy intellektuális fogyatékosságának sokszínűségéből, hanem sokkal inkább az egységes módszertani követelmények hiányából, pontosabban elavultságából fakad. Az igazságügyi pszichiátriai szakértői vizsgálatokról és véleményezésről az Országos Igazságügyi Orvostani Intézet által 2005. május 31. napján kiadott 14. sz. módszertani levél tartalmaz formai és tartalmi követelményeket. Ennek a 14. sz. módszertani levélnek az elöírásai 2011 óta azonban már nem alkalmazhatók, ugyanakkor új, korszerü, a tudomány mai állásának megfelelő módszertani útmutatás hiányában a gyakorlatban az igazságügyi elmeorvos szakértők vizsgálatuk során továbbra is ennek elöírását követik (vagyis a gyakorlat ebben is bizonytalan, eltérő megoldásokat mutat). Azonban még ez a „szokásjogban” tovább élő módszertani levél polgári ügyekkel foglalkozó I./B. része, illetőleg az igazságügyi elmeorvos (pszichiáter)-szakértői vélemény megszerkesztésével foglalkozó II. része

17 Ilyen döntések: Debreceni Járásbíróság 56.P.23.875/2016/39. sz. ítélete, Budapest Környéki Törvényszék 14.Pf.21.639/2016/7. sz. ítélete. 
sem tartalmaz konkrét, a bíróság számára történő felhasználhatóságot elősegítő előírást. Nincs iránymutatás a szükséges részletezettség mértékére sem, ezért a szakértőtől függ, hogy adott esetben hat- vagy tizenhat oldalas szakvélemény születik. Ezek a jelentős különbségek érdemi hatással vannak a bíróság ítélkezésére is. Például a Székesfehérvári Járásbíróság utóbb hatályon kívül helyezett 3.P.21707/2015. sz ítéletében kizárólagosan a szakértői véleményre támaszkodott, aki leírta, hogy „(az alperes) belátási képessége tartósan és nagymértékben hiányzik". Az alperes hiába rendelkezik „részletes ismeretekkel a politika világáról” a szakértői véleményben foglaltak miatt a bíróság választójogának korlátozását rendelte el. Az egy évvel később megismételt eljárásban a 3.P.22.706/2016/20 sz. ítélet már megszüntette a gondnokságot, nagyban támaszkodva az alperes személyes meghallgatására és az ügyben keletkezett újabb szakértői véleményre, amely csak a mentális zavarra vonatkozóan tett megállapításokat.

A szakértői bizonyításról szóló 2014. december 19-én kelt kúriai joggyakorlatelemző csoport összefoglaló véleménye számos ponton érinti a fenti problémákat. A hetedik fejezet rögzíti, hogy a szakértői vélemény a bíróság ítéletét megalapozó, olyan objektív és egzakt bizonyítási eszköz, amely általában közvetlenül és nagymértékben kihat a bíróság érdemi döntéseire, továbbá befolyásolja a per befejezésének időpontját és költségeit is. A tanulmány kitér az egységes módszertani levelek hiányának problematikájára is, amellyel kapcsolatban megállapítja, hogy „amíg az egységes szakmagyakorlás alapelvei, a szakterület egységes szempontrendszere, módszertani megalapozottsága és a szakvéleménnyel kapcsolatos alapvető elvárások nincsenek megfogalmazva, addig a jogbiztonság bizonyos fokig csorbát szenvedhet”.

$\mathrm{Az}$ ombudsman szintén többször megállapította a módszertani levelek alkalmazhatóságának hiányából eredően a jogállamiság elvéből fakadó jogbiztonság követelményével és a tisztességes eljáráshoz való joggal összefüggésben fennálló viszszásságot. ${ }^{18}$

Ahogy tehát a Kúria és az alapjogi biztos is többször és hangsúlyosan megállapította, mindennapos alapjogsérelmet okoz az egységes és hatályos módszertani levél hiánya. Ilyen, egységes módszertan híján pedig a szakvélemények szakmai megalapozottsága a szakértő egyéni rátermettségétől függ. Sürgető szükség mutatkozik tehát egy egységes és progresszív módszertani levél kiadására a gondnoksági eljárásokat illetően.

\section{A mentális zavar és a belátási képesség csökkenése közötti okozati összefüggés megállapitásával kapcsolatos bizonytalanság a szakértö és a bíró között}

A mentális zavar szükséges, de nem elégséges feltétele a cselekvőképesség korlátozásának. Amennyiben az igazságügyi szakértői vélemény megállapít valamilyen diagnózist, az még nem eredményezi automatikusan a belátási képesség általános és minden

18 Lásd: AJB-512/2013 számú ügy, illetve a 344/2018. sz. jelentés. 
ügycsoportra kiterjedő csökkenését. A mentális zavarnak a belátási képességre gyakorolt hatása a releváns, aminek az elemzése és az összefüggések meggyőző kimutatása azonban gyakran nem szerepel sem a szakértői véleményben, sem a bíróság ítéletében.

A vonatkozó jogszabályok szerint a szakértő csak a mentális állapotról nyilatkozhat (lásd 1. feltétel), a belátási képesség mértékének megállapítása (2. feltétel), és ez alapján az egyes ügycsoportokban a cselekvőképesség korlátozása már jogkérdés, mert jognyilatkozatok megtételére való önálló képesség vizsgálatát célozza. Ez a bizonyítási eljárás teljessége alapján dönthető csak el, amely bizonyítást csak bíróság folytathat le, ezért a belátási képesség megítélése a bíróság kompetenciája. Ehhez a szakértői vélemény beszerzésén túl a bíróság tanúkat idéz, és személyesen meghallgatja az érintett felet. E szempontok szerint járt el a Debreceni Járásbíróság, és hozta meg az 56.P.23.875/2016/39. számú ítéletét, amelyben részletezte és világosan rögzítette a szakértő és a bíróság közötti kompetenciahatárokat, külön kiemelve, hogy „a szakértő csak a mentális zavar fennállásában nyilatkozhat". Szintén ennek mentén hozta meg a Miskolci Járásbíróság a 19.P.22.798/2012/99. sz. ítéletét, amelyben kimondta, hogy nem elégséges kizárólag a szakértői véleményre hivatkozni. ${ }^{19}$ Ezzel szemben, általános gyakorlatnak tünik, hogy a bíró már a szakértőt kirendelő végzésében arra kéri fel a szakértőt, hogy „a mentális állapot felmérését követően nyilatkozzon arról, hogy az alperes rendelkezik-e az ügyei viteléhez szükséges belátási képességgel az egyes ügycsoportok tekintetében", valamint nyilatkoztatja a szakértőt, hogy gondnokság alá helyezés indokolt-e. Az a szakértői vélemény, amely e kérdések mentén születik meg, lényegében a bíró helyett hozza meg a döntést.

Általános tapasztalat, hogy a bíróságok nagymértékben támaszkodnak a szakértői véleményekre, sőt esetenként kizárólag a szakértői vélemény alapján hozzák meg döntéseiket, szó szerint átvéve a szakértői véleménynek a belátási képességre vonatkozó megállapításait, elmulasztva annak összevetését az egyéb bizonyítékokkal. Ez a gyakorlat jogellenes, hiszen a szakértői vélemény - ugyan az egyik legfontosabb -, mégiscsak az egyik bizonyíték a perben, amely ténykérdéseket tartalmaz. Bár a gondnoksági perek úgynevezett szakértői perek, az ítéletet a bíró hozza, amely az aggálytalan szakértői véleményből és más bizonyítékokból levont jogi következtetésekből kell, hogy létrejöjjön. Ilyen ítélet született a Pesti Központi Kerületi Bíróság 17.P.103.908/2015. sz. ügyben, a Körmendi Járásbíróság 2.P.20.357/2014. sz. ügyében, amelyben a szakvélemény a gondnokság szükségességéről is rendelkezett. A kirendelt szakértő a véleményében nyilatkozott a vizsgált személy belátási képességéről például a Miskolci Törvényszék, mint másodfokon eljáró bíróság előtt folyt 1.Pf.21.337/2015. sz. ügyben, a Veszprémi Járásbíróság, mint elsőfokon eljárt bíróság előtt folyt 8.P.21.034/2013. sz. ügyben, a Debreceni Járásbíróság előtt

19 Lásd még: Gyulai Járásbíróság, a 5.P.20.277/2017. sz. ügyben, a Budapesti XVIII. és XIX. kerületi Bíróság a 6.P.XVIII.21.890/2016. sz ügyben, a Budaörsi Járásbíróság 2.P.20.635/2015/35. sz. ítéletében. 
folyt 56.P.23.875/2016. sz. ügyben, a Székesfehérvári Járásbíróság előtt zajlott 3.P.21707/2015. sz. ügyben.

A szakvélemény akkor képes betölteni feladatát, ha a szakértő és a bíróság a jogszabályi kereteket megtartva jár el. Bár a gondnoksági perek eldöntése szempontjából alapvető jelentőséggel bír a mentális zavar fennállására vagy fenn nem állására irányuló szakkérdés megállapítása, a belátási képesség csökkenése mértékének eldöntése és ez alapján a jogkorlátozás szükséges mértékének meghatározása, azaz az ügycsoportok meghatározása a bíróság feladata, amely döntés meghozatalát semmilyen körülmények között nem terhelheti a szakértőkre. Bár az írott jog ebben a kérdéskörben világos, a jogalkalmazás - tapasztalataink szerint - rendkívül eltérő megoldásokat alkalmaz, gyakran jogellenesen, lényegében a szakértőre bízva a döntéshozást.

\section{Egyéni körülmények, társadalmi kapcsolatok súlyának jelentösége}

A gondnokság alá helyezésnek harmadik, konjunktív törvényi feltétele az érintett egyéni körülményeinek, családi és társadalmi kapcsolatainak vizsgálata. ${ }^{20} \mathrm{Nem}$ egységes a jogalkalmazás azonban abban a kérdésben, hogy mekkora jelentőséget tulajdonít az érintett fél egyéni körülményei feltárásának és figyelembevételének. Márpedig, a családi, szociális háló feltérképezése és annak az érintett fél életében játszott szerepének megítélése kulcsfontosságú annak megállapítása szempontjából, hogy szükséges-e, és milyen mértékben az érintett jogainak korlátozása.

A Budapest Környéki Törvényszék mint másodfokon eljáró bíróságnak az 1.Pf.21.698/2017/6. sz. ítéletében a hatályon kívül helyezés egyik oka éppen az volt, hogy az elsőfokon eljáró Nagykátai Járásbíróság nem tárta fel kellő súllyal az egyéni körülményeket. Tapasztalataink szerint hiába beszélgetnek el alaposan a bírák az érintett féllel, személyes meghallgatása során, hogy felderítsék az egyéni és társadalmi körülményeket, később ezeknek az információknak lényegesen kisebb jelentőséget tulajdonítanak, mint a szakértői véleménynek, amely adott esetben az orvosi előzményi iratokon túl csak egy néhány perces személyes elbeszélgetésen alapul.

\section{Az érintett fél személyes meghallgatása}

A per során a bíróság meghallgatja az érintett felet, és próbálja felmérni a belátási képességét. A gondnoksági perek során talán ennek kapcsán tapasztaljuk a legnagyobb jogalkalmazói eltéréseket. Tekintettel arra, hogy az érintettek pszichoszociális vagy intellektuális fogyatékossággal, illetve autizmussal élő emberek, a könnyen érthető kommunikáció fontosságát nem lehet eléggé hangsúlyozni. Vannak bírók, akik elbeszélgetnek az érintettel, hogy felmérjék, milyen taktikákat alakított ki arra, hogy megbirkózzon a mindennapi nehézségekkel. Például így derült ki a PKKB 19.P.102.422/2015. sz. ügyében, hogy az érintett fél, aki számolási nehézségekkel küzd,

20 A Ptk. 2:19. $\mathbb{S}(2)$ és 2:21. $\mathbb{S}(2)$ bekezdések megfogalmazása alapján „egyéni körülményeire, valamint családi és társadalmi kapcsolataira tekintettel". 
boltba indulás előtt párjával kiszámolja, hogy nagyjából mennyit kell majd fizetnie, és csak annyi pénzt visz magával. A bíró ezt úgy értékelte, hogy az alperes tisztában van a nehézségeivel és a saját korlátaival, azaz van belátása saját mentális nehézségére. Más bírók azonban sokszor jogi képzettséget feltételező tárgyi tudást mérő kérdéseket tesznek fel: a Tapolcai Járásbíróság 2.P.20.060/2017. sz. ügyében az intézetben élő érintettet arra kérte a bíró, hogy ismertesse a kezesi felelősségvállaló szerződést és annak következményeit. Az ehhez hasonló kérdések az átlag állampolgár számára is gyakran megválaszolhatatlanok, így a gondnokság alá helyezés szükségességét sem indokolják. A tárgyalóterem szokatlan és idegen környezete ráadásul fokozott szorongást kelthet pszichoszociális vagy intellektuális fogyatékossággal, illetve autizmussal élő emberekben, akik emiatt bizalmatlanná, visszahúzódóvá válnak. A meghallgatott fél zavara, értetlensége azt a hatást keltheti, hogy nincs tisztában azzal, hogy mi történik körülötte, holott egy nyugodtabb, ismerős helyen ugyanazokra a kérdésekre lényegesen nagyobb arányban tudna helyesen válaszolni. Jelezzük, hogy a kizárólag verbális bírói és szakértői kommunikáció nyilvánvaló hátrányba hozza a verbális kommunikációs akadályozottsággal élő felnőtt személyeket, akik sokszor pusztán a kommunikáció nehezítettsége miatt kerülnek jogkorlátozó helyzetbe, noha belátási képességük csökkent volta nem kimutatható. Például kommunikációs akadályozottsága miatt, egy téves szakértői diagnózis alapján helyezte cselekvőképességet kizáró gondnokság alá az alperest a Zalaegerszegi Városi Bíróság 15.P.21.521/2004/8. sz. ítéletével, majd ezt a hibát felismerve, a gondnokság alá helyezést teljesen megszüntette a Szigetvári Járásbíróság 12.P.20.101/2016/21. sz. ítéletével. A személyes meghallgatásnak rendkívül nagy szerepe van a belátási képesség megállapításában, ezért kulcsfontosságú, hogy az egységes szakmai szempontok szerint történjen. Ha az érintett nem érti, hogy mi történik a tárgyaláson, nem tud azon érdemben részt venni, ezzel súlyosan sérül a joghoz való hozzáférése, és ezáltal alapvető jogai.

A bírák egyéni rátermettségétől és tapasztalatától függ, hogy a meghallgatás valós képet eredményez-e az érintett fél mentális állapotáról, vagy esetleg puszta formalitássá válik. Szükség mutatkozik egységes iránymutatásra, módszertanra a belátási képesség bíróságok által történő felmérésére vonatkozóan. Hasonlóan szükséges lenne a gondnoksági pereket tárgyaló bírák képzése pszichoszociális vagy intellektuális fogyatékossággal, illetve autizmussal élő emberekkel való könnyen érthető és támogató kommunikációs technikák alkalmazására, ehhez igazított kérdezéstechnika, az értő meghallgatás, a szorongás oldását elősegítő készségek megszerzése érdekében. Továbbá, célszerű volna a felsorolt kompetenciával rendelkező szakemberek bevonása akár bírósági segédszervek formájában.

\section{Az érintett fél akarata vagy érdeke}

Az ENSZ Egyezmény 12. cikk 4. pontja rögzíti, hogy „a részes államok biztosítják, hogy [...] a cselekvőképesség gyakorlására vonatkozó intézkedések tiszteletben tartják a személy jogait, akaratát és választásait”. A 12. cikkhez füzött kommentár 
hangsúlyozza, hogy a fogyatékossággal élő emberek feltételezett érdekeit védő helyettes döntéshozatali szemléletet fel kell váltania a fogyatékossággal élő emberek akaratát előnyben részesítő támogató szemléletnek, ideértve ezen emberek jogát a hibázásra, a rossz döntések meghozatalára is. Ennek ellenére a magyar Ptk. továbbra is az érintett érdekét tartja szem előtt, miközben rögzíti, hogy az eljáró bíróságnak figyelembe kell vennie az érintett fél akaratát is. Ezzel együtt, peres gyakorlatunkban az esetek nagyjából felénél kérdezte meg a bíró a felet, személyes meghallgatása során arról, hogy mit gondol a gondnokságról, illetve elfogadná-e azt. Figyelembe vette az érintett akaratát és ezt az ítélet indokolásában is rögzítette a Budai Központi Kerületi Bíróság 14.P.XI.30.980/2014/26. sz. ítéletével lezárt ügyében. Személyes meghallgatása során a Székesfehérvári Járásbíróság 8.P.21.437/2017 sz. ügyében eljáró bíró kérdezte a felet, hogy mit gondol a gondnokságról és elfogadná-e azt. Ezzel szemben csupán az életére vonatkozó általános kérdéseket kapott a Komáromi Járásbíróság 2.P.20.469/2016. sz. ügyében eljáró bírótól az érintett fél, akaratát nem tárta fel. Hasonlóan csak az egyéni és társadalmi viszonyainak feltárására szorítkozott a Budaörsi Járásbíróság a 2.P.20.635/2015. sz. ügyben.

Az ENSZ Egyezmény 3. cikk a) pontjában - legelső alapelveként - kimondja a saját döntés meghozatalának szabadságát. Szükséges lenne annak mélyreható vizsgálata, hogy a bíróságok miként veszik figyelembe az érintettek akaratát, vagyis hogyan biztosítják választását az életére vonatkozó alapvető kérdésben. Álláspontunk szerint, kizárólag az érintett felek akaratának előnyben részesítésével biztosítható, hogy az intézkedés tiszteletben tartsa a személy jogait, akaratát és választásait, arányos és a személy körülményeire szabott legyen (ENSZ Egyezmény 12. cikk 4. pont). Amíg a magyar jogalkotás nem reagál az érintett feltételezett érdeke, és a saját maga által kifejezett akarata közötti különbségre, a jogalkalmazókra hárul a feladat, hogy a szemléletváltást elősegítsék, az érintettek akaratát figyelembe vegyék, illetve előnyben részesítsék.

\section{A választójog korlátozásának eltérő bírói gyakorlata}

Nem egységes az ítélkezési gyakorlat abban a kérdésben sem, hogy a választójog gyakorlásához szükséges belátási képességet külön vizsgálja a bíróság, vagy a belátási képesség csökkenésének megállapítása után automatikusan korlátozza azt a belátási képesség „általános” csökkenése miatt. A választójog gyakorlásához szükséges elmeállapotot általában az orvosszakértő is vizsgálja, de erre a bírák a fél személyes meghallgatása során is ki szoktak térni néhány, a közéleti tájékozottságra vonatkozó kérdéssel. Az első fokon eljáró Nagykátai Járásbíróság a 8.P.20.389/2016. sz. ügyben külön indokolás nélkül zárta ki a választójogból az érintettet. Az eljárás során nem vizsgálta a választójogot, de végül nem is korlátozta azt a 9.P.20.804/2015. sz. ügyben első fokon eljáró Szentendrei Járásbíróság. Külön vizsgálta, végül nem korlátozta, de ennek indokolását szintén elmulasztotta a PKKB a 17.P.103.908/2015. sz. ügyben. Olyan is előfordult, hogy a szakértő vizsgálata során megkérdezte a vizsgált személy- 
től, hogy „alkalmasnak tartja-e magát közéleti szerepvállalásra”. Bár a vizsgált személy mértéktartó és adekvát válaszokat adott, a szakértő véleményében mégis úgy látta, hogy „bár széles körű politikai ismeretekkel rendelkezik, a politikai szerepvállaláshoz hiányzik a belátási képessége" - ezáltal különbséget téve aktív és passzív választójog között. ${ }^{21}$

Az ítéleteket áttekintve azonban úgy tünik, nincs kimunkált módszertan annak a megállapítására, hogy milyen ismeretek, készségek, belátás szükséges ahhoz, hogy valaki gyakorolja a választójogát.

A választás joga nem kapcsolható a közéleti, politikai tájékozottság valamely meghatározott szintjéhez, így magának a választásnak, annak tényének és tétjének minimális ismerete már megalapozza a választáshoz való alkotmányos jog korlátozásának kizárását. Szükségtelen tehát vizsgálni azt, hogy egy-egy választó milyen szintű politikai ismerettel rendelkezik, hiszen akkor valamennyi állampolgárt egyfajta tesztnek kellene alávetni minden egyes választás, szavazás előtt, továbbá meg kellene határozni azt a tudásszintet, amely felett az adott szavazó élhetne alkotmányos jogával. Egy ilyen szabály az alkotmányos rendet sértő cenzusos választási rendszert eredményezne, amely jogállamban nem megengedhető. A fent előadottakon túl a nemzetközi emberi jogi normák és fórumok is rögzítik, hogy az érintetteket a belátási képességüktől függetlenül megilleti a választás, a közéletben való részvétel joga.

Az ENSZ Egyezmény 29. cikke szerint „a részes államok másokkal azonos alapon garantálják a fogyatékossággal élő személyek számára politikai jogaik élvezetét, és vállalják, hogy biztosítják, hogy a fogyatékossággal élő személyek másokkal azonos alapon, hatékonyan és teljes körűen vehessenek részt a politikai életben és a közéletben, közvetlenül vagy szabadon választott képviselőkön keresztül, beleértve a fogyatékossággal élő személyek jogát és lehetőségét a szavazásra és választhatóságra”. Az idézett 29. cikk tartalmával az Emberi Jogok Európai Bírósága is egyetért, azt határozataiban is alkalmazza. Két releváns ítéletében a Bíróság az 1989-es alkotmány alapján elrendelt általános és automatikus korlátozást ítélte egyezményellenesnek. ${ }^{22} \mathrm{~A}$ Bujdosó és társai kontra Magyarország ${ }^{23}$ egyedi panasz esetében, amelyet a CRPD Bizottság bírált el, a Bizottság az egyedi korlátozások rendszerét minősítette elfogadhatatlannak. A Bizottság határozata szerint: „A bizottság hangsúlyozza, hogy az Egyezmény 29. cikke alapján minden tagállamnak biztosítania kell, hogy a fogyatékossággal élő személyek hatékonyan és teljes körűen, másokkal azonos alapon vehessenek részt a politikai életben. Ez az elvárás a választójogra is vonatkozik. A 29. cikk nem tesz lehetővé semmilyen ésszerű korlátozást vagy kivételt a fogyatékossággal élő személyek csoportján belül. A választójog korlátozása valamely észlelhető vagy aktuális pszichoszociális vagy értelmi fogyatékosság alapján, beleértve az olyan korlátozást is,

21 Például: Székesfehérvári Járásbíróság 3.P.21707/2015 sz. ügye és a Székesfehérvári Járásbíróság 8.P.21.437/2017 sz. ügye.

22 Kiss Alajos v. Hungary (no. 2.), Judgement of 20 August 2010, no. 38832/06.; Gajcsi v. Hungary (no. 2.), Judgement of 23 September 2014, no. 62924/10.

23 Bujdosó és társai kontra Magyarország (CRPD/C/10/D/4/2011). 
amely egyéni vizsgálatra alapozódik, fogyatékosság alapján történő diszkriminációnak tekinthető az Egyezmény 2. cikkének értelmében." (9.4. bekezdés.) A Bizottság azt javasolta Magyarországnak, hogy a szavazati jog gyakorlásának kérdését válassza el a cselekvőképesség kérdésétől, és szavazást megkönnyítő támogató intézmények kiépítésére törekedjen. ${ }^{24}$

Álláspontunkat támasztja alá az alábbi két dokumentum is: Az Európa Tanács Miniszterek Tanácsa CM/Rec (2011) 14. számú, 2011. november 16-án közzétett ajánlása 3. pontja hasonló módon tiltja a nem teljesen cselekvőképes fogyatékos állampolgárok választójogának bármilyen korlátozását: „Minden fogyatékossággal élő személynek - legyen bár fizikai, érzékszervi, értelmi fogyatékossága, mentális problémája vagy krónikus betegsége - más állampolgárokkal azonos alapon kell biztosítani a választójogot. A fogyatékossággal élő személy e jogát cselekvőképességének korlátozása révén törvény nem vonhatja meg, és nem korlátozhatja bírósági vagy egyéb döntés vagy intézkedés, amely fogyatékosságára, kognitív képességére vagy valamely észlelhető képességének hiányára hivatkozik."

A Joggal a Demokráciáért Európai Bizottság (Velencei Bizottság) 584/2010. nyilatkozata hasonlóképpen az ENSZ Egyezmény 29. cikkét tekinti irányadónak a kérdésben: „Az egyetemes választójog az európai választójogi örökség alapvető elve. A fogyatékossággal élő embereket - a Fogyatékossággal élő személyek jogairól szóló ENSZ Egyezmény 29. cikkének megfelelően - ebben a tekintetben nem érheti hátrányos megkülönböztetés."

A fentiek alapján álláspontunk szerint megállapítható, hogy bármely fogyatékossággal élő személynek joga van arra, hogy választójogát gyakorolja függetlenül mindenkori állapotától.

\section{Az ügygondnokok szerepe}

A Pp. 438. \$ (2) bekezdése szerint a perben az érintett fél részére a keresetlevél kézbesítésével egyidejűleg ügygondnokot kell kirendelni. A szabály célja, hogy senki se maradjon képviselet nélkül, emellett azonban kiemelten fontos az ügyfél tájékoztatása, támogatása az eljárás során. Ehhez képest, némely kivételtől eltekintve - amikor aktív volt az ügygondnok a PKKB, 9.P.103.486/2013. sz. ügyben, és jelentősnek mondható a szerepe a Budai Központi Kerületi Bíróság elött 14.P.XI.30.980/2014. sz. ügyben is -, azt tapasztaljuk, hogy az ügygondnok szerepe a gondnokság alá helyezési eljárásokban formálisnak mondható. Jellemzően az ügygondnok az első tárgyalás előtt nem keresi fel személyesen az érintettet, nem kérdezi meg álláspontját, és ténylegesen nem képviseli jogait, érdekeit (például nem él a jogorvoslati joggal). ${ }^{25}$

Célszerü lenne pontosabban definiálni az ügygondnok szerepét és feladatát a képviselt személyek egyéni szükségleteire tekintettel, így elsősorban szerepét az érintett

24 Committee on the Rights of Persons with Disabilities Communication No. 4/2011.

25 Lásd: Komáromi Járásbíróság 2.P.20.469/2016. sz. ügyben, Budapesti XVIII. és XIX. kerületi Bíróság, 6.P.XVIII.21.890/2016. sz. ügyben, a Budaörsi Járásbíróság 2.P.20.635/2015. sz. ügyben. 
akaratának felderítésében, annak képviseletében, előzetesen érdemi tájékoztatás adásában, a tárgyalásokat követően az eljárási események megmagyarázásában.

Jogalkalmazásbeli bizonytalanságot szül az a helyzet is, hogy a törvény a kötelező képviseleten túl nem rendelkezik az ügygondnokok perbeli részvételéről, így bizonytalan helyzetet szül, ha az érintettnek van meghatalmazott képviselöje. A Pp. 438. $\mathbb{S}$ (2) bekezdésben foglalt szabályt a bíróságok jellemzően úgy értelmezik, hogy az ügygondnokot akkor is ki kell rendelni, ha az érintett félnek már van meghatalmazott jogi képviselője. A Székesfehérvári Törvényszék - többek között - éppen azért helyezte hatályon kívül az elsőfokon eljáró Székesfehérvári Járásbíróság 16.P.20.996/2017/21. sz. ítéletét, mert az eljárás során a bíróság elmulasztotta ügygondnok kirendelését, holott az minden gondnoksági perben kötelező. Ehhez képest a 8.P.21.437/2017. sz. ügyben a kirendelt ügygondnok már a legelső tárgyalás legelején felmentését kérte, tekintettel a meghatalmazott ügyvéd jelenlétére, amelyet a Székesfehérvári Járásbíróság eljáró bírója jóvá is hagyott. A 9.P.20.804/2015. sz. ügyben az elsőfokon eljáró Szentendrei Járásbíróság amint megkapta a jogi képviselő meghatalmazását, a már kirendelt ügygondnok kirendelését végzésével megszüntette és helyette az érintett fél által meghatalmazott jogi képviselőt rendelte ki ügygondnokként. Ezt a megoldást utóbb a másodfokon eljáró Budapest Környéki Törvényszék sem kifogásolta. ${ }^{26}$ Szintén a meghatalmazott jogi képviselő járhatott el ügygondnokként a Miskolci Járásbíróság 19.P.22.798/2012. sz. ügyében.

Tekintettel arra, hogy a kötelező jogi képviseletre vonatkozó szabály célja, hogy a pszichoszociális vagy intellektuális fogyatékossággal, illetve autizmussal élő emberek ne maradhassanak képviselet nélkül a peres eljárás során, így az ő képviseletük az általuk meghatalmazott jogi képviselő perbeli részvételével teljesül, nem szükséges duplikálni a fél jogi képviseletét ellátó személyét. Álláspontunk szerint téves tehát az a nyelvtani jogértelmezés, amely szerint akkor is kötelező ügygondnok jelenléte, ha a perben van az érintett által meghatalmazott jogi képviselő.

\section{Összegzés}

Immáron bő egy évtizede kötelezi a magyar államot a fogyatékos személyek jogairól szóló ENSZ Egyezmény, hogy a paternalista, súlyosan jogkorlátozó gondnoksági rendszert váltsa fel a támogató, alapjogokat tiszteletben tartó szemlélet. Ám hiába lépett öt éve hatályba az új Ptk., és lépett ezzel előre a mentális nehézségekkel küzdő emberek jogkorlátozása terén azzal, hogy bevezette a támogatott döntéshozatal lehetőségét, a bírósági gyakorlatban mégis az tapasztalható, hogy a legjobb esetben is csak színesítette a jogalkalmazási palettát az új jogintézmény, ám rendszerszerűen nem tudta megváltoztatni az uralkodó szemléletmódot, ítélkezési gyakorlatot.

Egy személy gondnokság alá helyezése a lehetőlegközelebbrőlés legmélyebben érinti az önrendelkezési jogát, magánéletéhez való jogát, végső soron emberi méltóságát.

26 Budapest Környéki Törvényszék 14.Pf.21.639/2016 sz. ügye. 
Az érintettek alapjogainak korlátozása ráadásul nemcsak formális, hiszen az esetek többségében maga után vonja családi-rokoni köréből való kiszakítását, intézményi elhelyezését is. Az ilyen súlyos jogkorlátozás esetén sorsdöntő kérdés, hogy szükséges-e, és ha igen, milyen mértékben szükséges és arányos az érintettek önrendelkezésének ilyen súlyos korlátozása. A tapasztalatok azonban azt mutatják, hogy a bíróságok gyakran elmulasztják a szükségességi és arányossági elv alkalmazását, aránytalanul korlátozva így a fogyatékossággal élő személyek alapjogait. A bírák gyakran azzal is sértik a fokozatosság elvét és a Ptk. konkrét rendelkezéseit is, hogy a belátási képesség csökkenésének megállapítását követően, a konkrét ügy körülményeire tekintet nélkül korlátoznak ügycsoportokat.

Külön hangsúlyozni érdemes, hogy további veszélyeket rejtenek magukban a gondnoksági perek, mint az úgynevezett „szakértői perek”, mert bevett gyakorlat, hogy az érintett gondnokság alá helyezését a bíróság kizárólag mentális helyzetétől teszi függővé. Különösen problematikus ez a gyakorlat annak fényében, hogy a szakértői vélemények egységes és szakmailag igazolható módszertan nélkül készülnek. Miközben a gondnokság alá helyezésnek három, konjunktív feltétele közül a másik két feltétel nem szakértői kérdés, hanem jogkérdés, így előállhat az a helyzet, hogy az ugyan mentális problémával küzdő személynek van belátása saját állapotára, így jogkorlátozása nem indokolt, vagy akár nincs is teljes belátása állapotára, de a támogató családi és szociális közege kellő segítséget nyújt ahhoz, hogy jogkorlátozása szükségtelennek bizonyuljon. Mindezen tényezők bírósági feltérképezéséhez azonban kell az is, hogy a bírák saját kompetenciájuknak tekintsék e jogkérdések megítélését, és hogy az eljárás alá vont érintettet, mentális és verbális lehetőségeihez mérten meghallgassák, akaratát megismerjék. Ebben kell továbbá az érintett kirendelt ügygondnokának is mint jogi képviselőjének a lehető legnagyobb mértékben sérülékeny ügyfelét támogatnia.

Amíg a helyettes döntéshozatali formát Magyarországon fel nem váltja az érintettek cselekvőképességét érintetlenül hagyó támogatott döntéshozatali forma, addig a jogalkalmazókra hárul a feladat, hogy a hatályos jogszabályoknak az egész országban egységes és pontos alkalmazásával, az érintettek akaratának figyelembevételével, autonómiájuk előmozdításával, a számukra legelőnyösebb, jogaikat tiszteletben tartó döntéseket hozzák meg. A jogalkalmazás egységességét biztosítandó, 2019-ben a Kúria öt joggyakorlat-elemző csoport felállításáról döntött. Az egyik csoport témája a cselekvőképességet korlátozó gondnoksági perek bírósági gyakorlata lesz. Bízunk benne, hogy jelen tanulmányunkkal is hozzájárulunk az egységes jogalkalmazáshoz.

Mindazonáltal fontosnak tartjuk hangsúlyozni, hogy a jogszabályváltozásokkal egyidőben szükség van társadalmi szemléletváltozásra is. Az ENSZ Egyezmény szellemiségének megfelelő támogatott döntéshozatali formák csak akkor lehetnek sikeresek, ha a fogyatékossággal élő emberekre a társadalom, mint önálló életvitelre képes, a társadalom aktív, egyenértékủ tagjaira tekint. 


\section{Felhasznált irodalom}

Concluding observations of the Committee on the Rights of Persons with Disabilities, Hungary (2012). UN, Geneva.

General Comment on Article 12: Equal Recognition before the Law (2014). CRPD/C/GC/1. Convention on the Rights of Persons with Disabilities. Elérhetö: http://tbinternet.ohchr.org/_layouts/ treatybodyexternal/Download.aspx?symbolno=CRPD/C/GC/4\&Lang=en (2019. 03. 20.)

Huszár Ilona - Kuncz Elemér (1998): Igazságügyi pszichiátria. Budapest, Medicina.

Mancini, Michael A. (2007): Narratives of Recovery from Serieus Psychiatric Disabilities: A Critical Discourse Analysis. Critical Approaches to Discourse Analysis across Disciplines.

Szociális statisztikai évkönyv - 2017 (2018). Budapest, KSH.

Joghalál az új Ptk-ban (2014). Budapest, TASZ. Elérhető: https://tasz.hu/cikkek/joghalal-az-ujptk-ban (2019. 03. 28.)

\section{Magyar bírósági döntések}

Budai Központi Kerületi Bíróság 14.P.XI.30.980/2014

Budaörsi Járásbíróság 2.P.20.635/2015

Budapest Környéki Törvényszék 1.Pf.21.698/2017, elsőfokon: Nagykátai Járásbíróság 8.P.20.389/2016

Budapest Környéki Törvényszék 14.Pf.21.639/2016, elsőfokon: Szentendrei Járásbíróság 9.P.20.804/2015

Budapesti XVIII. és XIX. kerületi Bíróság 6.P.XVIII.21.890/2016

Debreceni Járásbíróság 56.P.23.875/2016

Fővárosi Törvényszék 54.Pf.638.980/2015, elsőfokon: PKKB 9.P.103.486/2013

Gyulai Járásbíróság 5.P.20.277/2017

Komáromi Járásbíróság 2.P.20.469/2016

Körmendi Járásbíróság 2.P.20.357/2014

Miskolci Törvényszék 1.Pf.21.337/2015, elsőfokon: Miskolci Járásbíróság 19.P.22.798/2012

PKKB 17.P.103.908/2015

PKKB 19.P.102.422/2015

Székesfehérvári Járásbíróság 3.P.22.706/2016, fellebbezés folytán hatályon kívül helyezett: Székesfehérvári Járásbíróság 3.P.21707/2015

Székesfehérvári Járásbíróság 8.P.21.437/2017

Székesfehérvári Járásbíróság, 13.P.20.422/2015

Székesfehérvári Járásbíróság 16.P.20.996/2017

Szigetvári Járásbíróság 12.P.20.101/2016

Tapolcai Járásbíróság 2.P.20.060/2017

Veszprémi Törvényszék 1.Pf.20.263/2016, elsőfokon: Veszprémi Járásbíróság 8.P.21.001/2014

\section{Az Emberi Jogok Európai Bíróságának döntései}

Gajcsi v. Hungary (no. 2.), Judgement of 23 September 2014, no. 62924/10.

Kiss Alajos v. Hungary (no. 2.), Judgement of 20 August 2010, no. 38832/06.

Lashin v. Russia, Judgement of 22 January 2013, no. 33117/02.

Shtukaturov v. Russia, Judgement of 27 March 2008, no. 44009/05. 
Stanev v. Bulgaria, Judgement of 17 January 2012, no. 36760/06.

X. and Y. v. Croatia, Judgement of 3 November 2011, no. 5193/09.

\section{További jogforrások}

74/2009. (VII. 10.) AB határozat

Az alapvető jogok biztosának Jelentése az AJB 2709/2016. számú ügyben

A fogyatékossággal élő személyek jogairól szóló egyezmény Fakultatív Jegyzőkönyve. New York, 2006. december 13., Doc.A/61/611. Elérhető: https://net.jogtar.hu/jogszabaly?docid=a0700092 (2019. 01. 14.)

A fogyatékossággal élő személyek jogairól szóló egyezmény. New York, 2006. december 13., United Nations, Treaty Series, Vol. 2515.

A Polgári Törvénykönyvről szóló 2013. évi V. törvény

Bujdosó és társai kontra Magyarország (CRPD/C/10/D/4/2011) 